\title{
Lessons from the past: Historical perspectives of mental health in the Eastern Cape
}

\author{
K Sukeri, ${ }^{1} \mathrm{MB} \mathrm{ChB}, \mathrm{FCPsych}(\mathrm{SA})$; O A Betancourt, ${ }^{1} \mathrm{MD}, \mathrm{PhD}, \mathrm{FCPsych}(\mathrm{SA})$; \\ R Emsley, ${ }^{2} \mathrm{MB}$ ChB, DCH, MMed (Psych), FCPsych (SA), DMed, DSc \\ ${ }^{1}$ Department of Psychiatry, Walter Sisulu University, Mthatha, South Africa \\ ${ }^{2}$ Department of Psychiatry, University of Stellenbosch, Cape Town, South Africa
}

Corresponding author: KSukeri (ksukeri@telkomsa.net)

\begin{abstract}
The development of mental health services in the Eastern Cape Province is inextricably entwined in South Africa's colonial history and the racist policy of apartheid. Prior to the development of mental hospitals, mental health services were provided through a network of public and mission hospitals. This paper explores the development of early hospital and mental health services in the Eastern Cape from the time of the Cape Colony to the dissolution of apartheid in 1994, and highlights the influence of colonialism, race and legislation in the development of mental health services in this province. The objective is to provide a background of mental health services in order to identify the historical factors that have had an impact on the current shortcomings in the provision of public sector mental health services in the province. This information will assist in the future planning and development of a new service for the province without the stigma of the past. This research indicates that one lesson from the past should be the equitable distribution of resources for the provision of care for all that inhabit this province, as enshrined in South Africa's constitution.
\end{abstract}

S Afr J Psych 2014;20(2):34-39. DOI:10.7196/SAJP.568

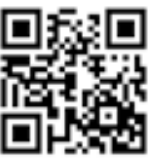

Mental healthcare provision in the Eastern Cape Province is inextricably entwined with the province's colonial past and, in later years, by the introduction of the policy of apartheid and the Bantustans. These laid the foundation for an inequitable distribution of mental health services in the province. The objective of this article is to provide a background for the historical factors that have had an impact on the provision of public sector mental health services. The archives of the British Medical Journal and the South African Medical Journal and universities in South Africa were accessed to obtain the information presented here.

History and geography played a pivotal role in shaping the Eastern Cape first into Bantustans and later the Eastern Cape Province in a democratic South Africa (SA) (Figs. 1 and 2). Mostert ${ }^{[1]}$ in his book, Frontiers: The Epic of South Africa's Creation and the Tragedy of the Xhosa People, states that the 'wars and moral struggle on the Cape frontier' affected the formative experience of SA, attitudes to colonialism and racism, and later of the political ideologies of Steve Biko and Nelson Mandela, whose ancestors were closely involved in these wars. The development of boundaries within the province influenced the location of both general and mental health facilities, therefore affecting access to and division of services along racial lines. The province has been the site of nine border wars (between 1779 and 1879) fought between the British and Dutch against the amaXhosa. ${ }^{[2,3]}$ It was against this backdrop of war and control of land that the province was annexed by the British. In 1819, the British parliament approved the spending of GBP50 000 towards the settlement of 5000 Europeans in the eastern regions of the Cape Colony to create a border guard between the settlers and the amaXhosa. ${ }^{[4,5]}$

The Transkei, originally referred to as Pondoland, was between the Kei River and the then Colony of Natal. More precisely, it was between the uMtata River to the south and the Umtamvuna River to the north. It occupied an area of approximately $47000 \mathrm{~km}^{2}$ and was progressively annexed by the British from 1874 to 1894 . Pondoland was the last region to fall under British control. ${ }^{[6,7]}$ The area was then divided into districts and the chiefs were reduced to overseers, only able to hear civil cases under native law.

The Ciskei was already part of British Kaffraria, with King William's Town as the capital city. ${ }^{[3]}$ British Kaffraria consisted of land between the Keiskamma and Kei Rivers, and was subdivided into seven counties. ${ }^{[8]}$ After the union of SA in 1910, British Kaffraria became known as the Border region.

Sir George Grey, the Governor of the Cape Colony from 1854 to 1861, was instrumental in developing a segregationist rule. His objective was to subordinate the chief's authority to the British government. ${ }^{[9]}$ Henderson ${ }^{[10]}$ writes that Grey was interested in the cooperation of the 


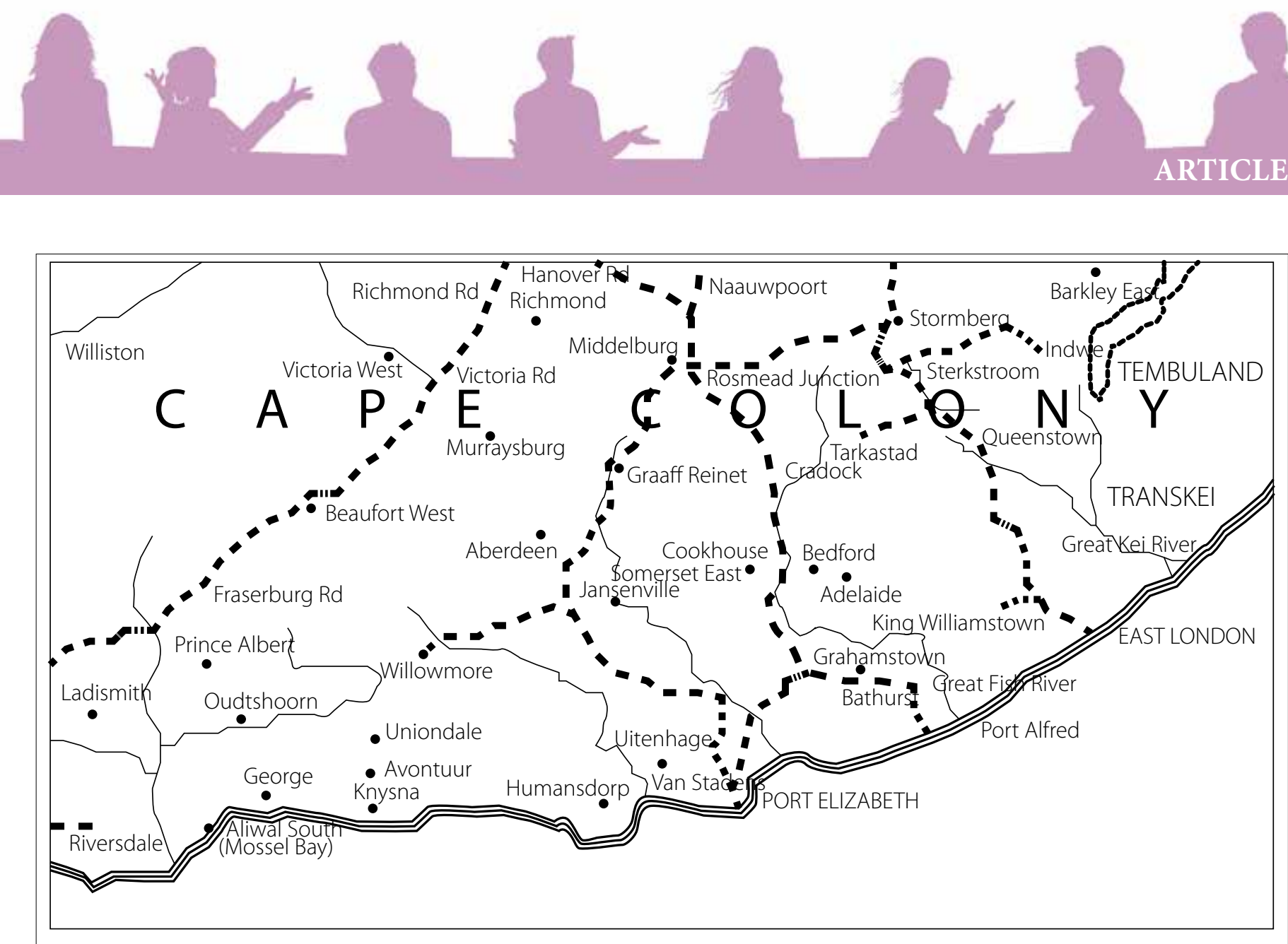

Fig. 1. Boundaries of the Cape Colony.

two races but not on an equal basis. Grey was of the opinion that the industrial relationship between the 'European and the Kaffir should be that of employer and employee'. A significant victory for colonial authorities was the cattle killings that occurred between April 1856 and May 1857. Following the visions of a prophetess, the amaXhosa killed approximately 400000 cattle on both sides of the Kei. This forced submission to the colonial government and almost all the land of the AmaXhosa was given to white immigrants or black officials of the colonial government. ${ }^{[11,12]}$

\section{Early health services in the Eastern Cape}

Prior to the development of asylums in the eastern regions of the Cape Colony, mentally ill patients were not only 'admitted' to jails but were also treated at general hospitals. ${ }^{[13]}$ This was particularly true for the Bantustan of the Transkei, which depended on mission hospitals to provide services.

In British Kaffraria there were no health services for the entire populace, white or black, until the establishment of Grey Hospital in King William's Town in 1856. This was a natives-only hospital, but indigent Europeans were also admitted. The hospital was originally situated in a pensioners' village and consisted of 20 cottages. Dr John Patrick Fitzgerald was appointed the first superintendent of native hospitals and held this post from 1856 to 1884 . The hospital served British Kaffraria and Pondoland. ${ }^{[14-16]}$ In April 1893, trained nurses were introduced in the hospital and they had native assistants. ${ }^{[17]}$ The hospital was declared a national monument in 1971 and continues to function as a district hospital today. ${ }^{[15]}$

Two years after the opening of Grey Hospital, the Albany Hospital in Grahamstown was opened. ${ }^{[18]}$ This hospital treated the mentally ill

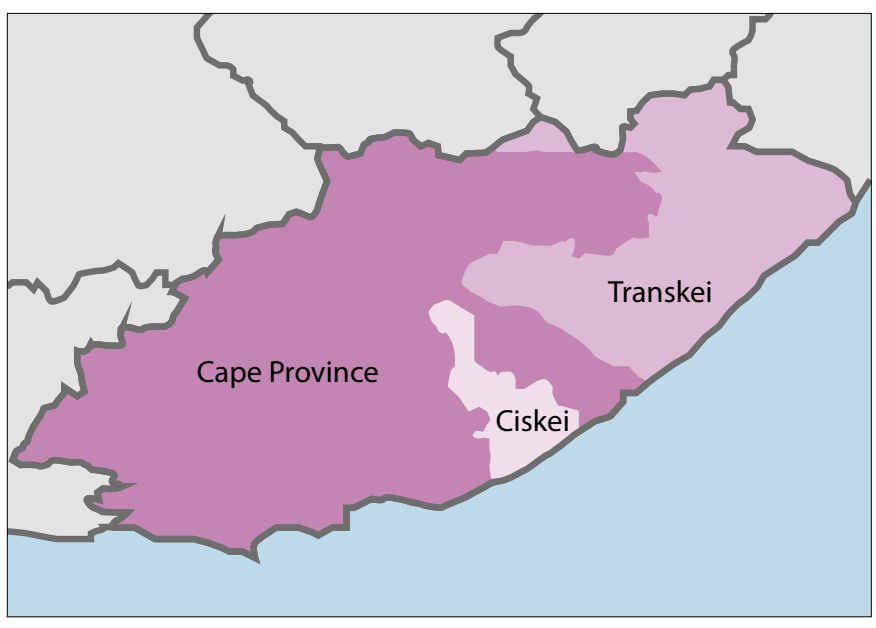

Fig. 2. The Bantustans of the Ciskei and Transkei.

as well as the chronically sick. In 1923, the hospital was moved to the current site of the Settler's Hospital. ${ }^{[18]}$ Grey, Albany, Frontier and the Provincial Hospitals were the only hospitals in the Eastern Cape until 1881, when Frere Hospital in East London was established. ${ }^{[10]}$ This hospital was for the treatment of both natives and whites. Initially it housed nine patients, and by 1889 the hospital had 26 beds and eight wards. In 1932 the hospital was extended to accommodate 202 beds, and by 1956 the hospital had 456 beds. ${ }^{[16]}$

It was only in 1882 that a hospital was established to serve most of the Transkei; Butterworth Hospital, which received patients from all over the Transkei, was opened. It was maintained in part by taxes collected from the Fingos, which was two shillings and six pence for 
'each man. ${ }^{[19]}$ Victoria Hospital at the Lovedale Mission and Umtata Hospital were provincial hospitals and were therefore state aided. By 1909, these hospitals had 18 and 17 beds, respectively, serving mainly the native population. ${ }^{[20]}$ The number of beds for natives increased to 186 at Umtata Hospital by 1943, with an additional 35 beds for Europeans and 10 beds for coloureds. ${ }^{[2]]}$

Mission hospitals contributed significantly to the development of health services in the Eastern Cape; $\sim 60 \%$ of beds for the native population in the Transkei were provided by mission hospitals. ${ }^{[21]}$ When the Transkei became an 'independent state' in 1976, all mission hospitals came under the control of the Transkeian government.

\section{Development of psychiatric services}

Mental institutions in the Eastern Cape were initially converted military barracks or prisons. The first facility was the Grahamstown Lunatic Asylum, established within the Fort England barracks in 1875. ${ }^{[22]}$ Prior to this, a hut was being used as a makeshift hospital and later patients were kept in the Albany Hospital. ${ }^{[18]}$

Dr Robert Hullah was the superintendent from 1876 to 1890 , followed by Dr Thomas Duncan Greenlees. On the recommendation of Dr Greenlees, the colonial government founded the Institute for Imbecile Children in Grahamstown in 1894. Dr Greenlees was superintendent of both these institutions as well as the Hospital for the Chronic Sick, which also admitted people diagnosed as insane. ${ }^{[18]}$

The Grahamstown asylum admitted both Europeans and nonEuropeans, although in his 1904 report on the institution, Dr Greenlees made an appeal for white lunatics to be treated apart from the coloured and native races. ${ }^{[23]} \mathrm{A}$ large number of private patients were admitted here, with Greenlees offering services such as picnics and in some cases the provision of champagne; this service was for whites only. Black patients were involved in manual labour, such as doing laundry and farm work. Black men provided the labour force in 'the guise of occupational therapy. ${ }^{\text {'24] }}$ Greenlees was of the opinion that black female patients did not require walks as this would interfere with the operational requirements of the asylum. ${ }^{[24]}$ In 1908, the asylum became a whites-only facility. ${ }^{[25]}$ It was only in 1952 that a separate ward for non-whites was created. ${ }^{[22]}$

Due to the overcrowding experienced at the Grahamstown Lunatic Asylum, the colonial government took over the barracks at the Kowie River in 1888 and converted this into the Port Alfred Asylum. ${ }^{[18,26]}$ There are conflicting reports about whether this facility was for whites only or all races. According to Terreblanche, ${ }^{[27]}$ the hospital was initially for whites only, however records show that in 1892 there were 36 nonwhites admitted. Jones ${ }^{[28]}$ states that the Kowie Hospital was found unsuitable for white occupation and was purely for non-whites.

The colonial government recognised the need for a natives-only hospital, and in 1894 took over the military barracks in Fort Beaufort and converted it into the Fort Beaufort Asylum, for natives only. Dr John Conry was the first superintendent. Dr W J Dodds, the Inspector for Asylums, complained that there was insufficient accommodation at Fort Beaufort and an open air shelter was created for ten male tuberculosis patients. ${ }^{[20]}$ The hospital was considerably extended with the building of huts in 1908, and a 60-bed male ward was added in 1913. ${ }^{[22]}$ The 'hut annex' was commissioned by Conry as a means of cheap accommodation for the black insane, which resulted in a saving of GBP6 850 for the colonial government. ${ }^{[25]}$
There was a high incidence of scurvy and tuberculosis at this institution. A contributing factor could have been the poor nutrition that patients received. This was probably because of the lesser allocation given to Fort Beaufort Asylum compared with other asylums in the colony. In 1909, Valkenberg Asylum had a nett expenditure of GBP7 480 per annum for a daily average of 410 patients compared with Fort Beaufort's per annum nett expenditure of GBP6 535 for a daily average of 475 patients. ${ }^{[25]}$

Fort Beaufort Asylum was administered by the Ciskei government from 1981 to 1994, when Ciskei was incorporated into SA. Today, the hospital, known as Tower Hospital, receives patients from the entire province and serves as the only state rehabilitation centre for psychiatric patients in the region.

These three asylums, Grahamstown, Port Alfred and Fort Beaufort, shared an institutional culture insofar as they were visited by $\mathrm{Dr}$ Dodds, Inspector for Asylums, whose reports were distributed to all asylums. Superintendents gained experience from working at other asylums and case notes on patients were exchanged. Swartz ${ }^{[25]}$ further states that the hierarchy of status in society was strictly maintained within the walls of the asylum. Black patients were transferred to Fort Beaufort Asylum and overflow patients from other asylums in the colony were transferred to Port Alfred Asylum.

Queenstown Mental Hospital was established in 1922. It was the only hospital at that time built specifically to accommodate the mentally ill. Within 15 years the hospital was expanded to include vegetable gardens, a dairy and a butchery. ${ }^{[22]}$ The hospital admitted both whites and non-whites in separate sections.

In Port Elizabeth, the mentally ill were transferred to Grahamstown Asylum or lodged in the local hospital. In 1969, the Elizabeth Donkin Hospital, originally opened in 1937 as an infectious diseases hospital, was converted into a psychiatric hospital. ${ }^{[29]}$

In Umtata, patients were treated at local mission hospitals or transferred to Fort Beaufort Asylum. It was only in 1976 that the Transkei government established a psychiatric facility. This is discussed further in the next section.

\section{Legislation and its effects on mental health services}

The earliest legislation regarding mental health services in the Cape Colony dates back to Ordinance No. 5 of 1833, which was amended in 1837 with Ordinance No. 3. These ordinances did not govern the provision of mental health services, and dealt only with the protection of the property of the insane. ${ }^{[22]}$

Parle ${ }^{[30-32]}$ and Swartz ${ }^{[33]}$ report that colonial psychiatry shadowed colonial government policy in terms of putting in place practices that had racist effects, such as inadequate accommodation for black patients and scientific justifications for diagnosis that treated white and black patients as biologically different groups.

The Mental Disorders Act No. 38 of 1916 brought the control of all mental hospitals under the Commissioner for Mental Hygiene, Dr J T Dunston. This act promoted custodial care and remained in effect for 56 years, replaced by the 1973 Act. $^{[34]}$

Other legislation also greatly affected the development of mental and health services in the country. The movement of the non-white population from one province to another and within a province was greatly affected by various legislations. This entrenched the 
development of a segregationist society and therefore a fragmented health system.

As early as 1857 , the movement of amaXhosa into the colony was governed by the so-called pass acts, which included the Kaffir Pass Act No. 23 of 1857 and the Kaffir Employment Act No. 27 of 1857. ${ }^{[35-38]}$

In 1913, after the establishment of the Union of SA and the Native Land Act No. 27 of 1913, blacks were no longer able to purchase or lease land outside of designated reserves. These reserves were later to become 'Bantustans.' Seven years later, the Native Affairs Act No. 23 of 1920 established a native affairs commission, which provided for a system of local councils in the reserves, and by 1927 the Union government had promulgated the Native Administration Act No. 38 of that same year. This act allowed the minister to, without prior notice to any persons, order any tribe or portion thereof to move from one place to another within the union. ${ }^{[35-38]}$

By 1948, the policy of apartheid ensured that health services in the Republic of SA were segregated by race. Health facilities were centralised within the republic. The apartheid government ensured a segregation of mental health services, favouring the white populace. There was a maldistribution of health workers and inequity in access of healthcare for different groups. ${ }^{[39]}$

In 1951, the Bantu Authorities Act No. 68 of 1951 allowed for the creation of traditional tribal, regional and territorial authorities, initially run by the Native Affairs Department but with the promise of self-government in the future. ${ }^{[35-38]}$

This was the prelude to the development of the Bantustans of the Ciskei and the Transkei. In 1961, the SA government declared the Ciskei a separate administrative authority. The Bantu Citizenship Act of 1970 defined blacks living throughout SA as legal citizens only of the homelands designated for their particular ethnic group, thereby stripping them of their SA citizenship. These homelands gained independence in 1976 (Transkei) and 1982 (Ciskei). ${ }^{[35-38,40,41]}$ The provision of health services were now the onus of these 'independent' homelands.

In the Ciskei, Fort Beaufort Asylum and Cecelia Makiwane Hospital, in the native reserve of Mdantsane, provided mental health services. The Transkei government, in 1977, took over the administration of approximately 22 mission hospitals and the state-aided hospitals, Umtata and Butterworth. ${ }^{[42]}$ Chief Moshesh, the Minister of Health in the Transkei, inaugurated the first psychiatric hospital in May 1976. The hospital, with 440 beds, was established on the grounds of the Mbizweni Prison and was called the Umzimkulu Hospital. Dr William Guy Daynes was the first superintendent. The hospital was incorporated into the province of KwaZulu-Natal in 2001. ${ }^{[43,44]}$

Dr Daynes established a psychiatric clinic at the Umtata Hospital. He went on to become the superintendent of Umtata Hospital and assist with the development of the medical faculty. ${ }^{[45]}$ It was only in 1985, with establishment of the Medical School at the University of Transkei, that a 14-bed unit for mentally ill patients was created at the Umtata Hospital. This was the status quo in the homeland until 2005.

The World Health Organization's report on apartheid and mental healthcare ${ }^{[46]}$ condemned the state of SA psychiatry. The report included descriptions of overcrowded black wards surrounded by wire mesh fences. It pointed out that the type and quality of mental healthcare was determined by the colour of one's skin. However, a racist policy on the treatment of the mentally ill was already in situ as early as 1854 . A report on the Robben Island Asylum ${ }^{[47]}$ clearly states that 'white inmates whether insane or lepers, should be kept separate from the blacks ...' It can therefore be argued that the policy of apartheid entrenched an existing racist policy in mental health.

Treatment modalities followed a similar pattern, with the prevailing notion that black Africans had a primitive personality. Even diagnosis was influenced by race, with Dunston in 1922 stating that the reason for no case of paranoia being diagnosed in the native population was owing to their inferior mentality. Dunston was of the opinion that blacks demonstrated a far lower level of intelligence than whites. ${ }^{[13]}$

Dunston initiated the mental hygiene movement in SA and was instrumental in the development of the Mental Disorders Act of 1916. ${ }^{[13,48]}$ Another prominent Eastern Cape medical practitioner, Dr Darley Hartley, supported the mental hygiene movement as owner, editor and publisher of the South African Medical Record. Dr T D Greenlees, the superintendent of the Grahamstown Asylum, was also a supporter of this movement. ${ }^{[13,48-50]}$

The government enlisted private contractors to provide care for mainly black patients in long-stay facilities. These facilities were owned by Smith Mitchell \& Co. This private enterprise provided $40 \%$ of all psychiatric beds in SA, 94\% reserved for black patients. In the Eastern Cape, the company provided 700 beds in Kirkwood, Port Elizabeth. ${ }^{[13,46,51]}$ A WHO report in 1983 condemned the poor hygiene standards and levels of care afforded to the black patients. ${ }^{[46]}$

Health budgets were segregated according to population classification, resulting in an inequitable distribution of resources. Zwarenstein and Price ${ }^{[52]}$ reported that the homelands and rural areas had the lowest number of hospital beds per capita and recommended that non-racial access to hospital care would achieve more health benefit for the same expenditure.

In East London, separate health services were already in existence since 1922, with the passing of the Public Health Act No. 36 of 1919. This was evident with the establishment of a whites-only in-patient service in $1931 .{ }^{[53,54]}$ A community psychiatric service was well established for the white and coloured population. Blacks were attended to in the native reserve of Mdantsane.

The Society of Psychiatrists of SA, now the SA Society of Psychiatrists, received severe criticism for their apparent support of the racist apartheid legislation. In 1978, a task team of the American Psychiatric Association found that the policy of apartheid resulted in discrimination of non-white patients treated in mental hospitals in SA ${ }^{[55-57]}$ In March 1985, the Council of the Royal College of Psychiatrists pointed out that there is substantial evidence that discrimination in the provision of psychiatric services based on race exists in SA both in State and Private Hospitals and that this discrimination in the provision of psychiatric facilities on the grounds of race is to us totally unjust and unacceptable. ${ }^{\text {?57] }}$

Sashidharan ${ }^{[58-61]}$ was vociferous in his criticism of SA psychiatrists. He referred to the racist practices of mental health professionals and their support of racist legislation, lack of facilities for non-whites and the psychological impact of apartheid. In their response, SA psychiatrists denied discrimination in mental health legislation, stated that as of 1982 there were seven black psychiatrists in SA and limited their report to services within white SA. ${ }^{[62,63]}$ No comment was made on the state of mental health services in the homelands, the facilities provided by Smith Mitchell \& Co or the fact that legislation was enacted 
by an apartheid regime and therefore inherently segregationist in its content. Burke ${ }^{[64]}$ reported that mental health legislation was used to admit 'idle' and 'undesirable blacks for indefinite periods of time.'

In October 1985, Sashidharan wrote to the Bulletin of the Royal College of Psychiatrists: '... it will take more than self congratulatory statements to convince us that medical institutions and psychiatrists in SA are not subservient to racist governmental policies in the field of health.'[61]

The Council of the Royal College of Psychiatrists, in 1987, adopted a resolution for sanctions against $S A .{ }^{[55,57]}$ Levine ${ }^{[65]}$ encouraged the members of the Society of Psychiatrists of SA to 'enter into a constructive dialogue about the problem of discriminatory provision of psychiatric services based on race.'

Racial differences strongly influenced the diagnostic practices of practitioners, with many psychiatrists working in public institutions arguing that black Africans and coloureds were not able to experience depression. Jones ${ }^{[28]}$ continued to emphasise that 'therapeutic applications were limited mainly to white men'. Jones agreed that no blanket statement could be made about all practitioners working in apartheid SA, but some psychiatrists did serve the interests of the apartheid state, while others did not (personal communication with principal author, Jones, February 2014.) Outside of the Bantustans, Dr George Hart expressed his dissatisfaction with the conditions for black patients at Sterkfontein Hospital. ${ }^{[28]}$

In his address to the American Psychiatric Association (APA) in 1997, Prof. Cliff W Allwood acknowledged that some members of the Society of Psychiatrists were involved in designing, implementing and defending state policies for the racial separation of psychiatric services. ${ }^{[66]}$

Together, the different pieces of legislation, racial segregation and the mental hygiene movement had a serious and deleterious effect on service provision for blacks in the country, particularly in the 'homelands'. In the Transkei and the Ciskei, there were no black psychiatrists. The Ciskei had non-Xhosa-speaking white psychiatrists who depended on interpreters. The Transkei had a resident black psychiatrist in 1991, with the establishment of the medical faculty at the University of Transkei.

In 1993, the Provincial Department of Health had the responsibility of amalgamating the three administrative areas of the Ciskei, Transkei and Cape Province to provide a comprehensive and integrated health service. It had to focus on re-addressing the inequities in health delivery during the apartheid era. This department inherited a fragmented service, with mental health services more developed in the former white areas of the province. Private mental health facilities were and are still situated in East London and Port Elizabeth, two former nodes of economic growth in apartheid SA.

A 1996 report titled Health Care in the Eastern Cape stated that there was an inadequate number of staff and facilities to provide a mental health service in the Eastern Cape. The report noted that the greatest area of need, in terms of psychiatric facilities, staff, access to mental healthcare in primary healthcare facilities and residential facilities was in the former homeland of Transkei. ${ }^{[67]}$

A further challenge that the Department of Health faced was the implementation of the Mental Health Care Act No. 22 of 2002. In 2006, the Department's annual report listed several constraints, such as inequity in the distribution of beds, insufficient number of beds in East London, Mthatha and Libode, challenges in implementation of the Mental Health Care Act, shortage of psychiatrists and an inadequate community psychiatric service. ${ }^{[68]}$

The Department of Health planned in 2006/7 to set up three task teams for the implementation of the Mental Health Care Act, identify 28 designated facilities and increase the number of psychiatric beds by $150 .{ }^{[68]}$ As of March 2014, the number of designated facilities in the Eastern Cape is eight and the bed status has remained unchanged.

\section{Conclusion}

The historical development of mental health services in the Eastern Cape has been greatly influenced by colonisation, the homeland policy and the legislation of the apartheid regime. The system of service delivery needs urgent revision, with the development of an integrated service that steers away from a vertical approach to the provision of health services.

It is clear that the need for psychiatric facilities in many areas requires urgent addressing. This is in particular reference to the paucity of services in the previous homeland of the Transkei. In 2001, the Umzimkulu Hospital was incorporated into the Province of KwaZulu-Natal, resulting in the loss of over 400 beds and total dependence on the Mthatha Mental Health Unit in that region. ${ }^{[69]}$

The marked lack of child and adolescent psychiatric services throughout the history of the province, particularly in the homeland states, is evident. Planning and provision of these services should be targeted at these regions particularly. More than 20 years after the appointment of the first black psychiatrist in Umtata, the number of non-white specialists in the province currently numbers three in state practice. The recruitment and retention of specialists should be a priority.

In Freeman' ${ }^{[70]}$ opinion, the objective of the Mental Health Care Act is to make the best possible mental healthcare, services and rehabilitation available to the population equitably, efficiently and in the best interests of mental healthcare users within the limits of the available resources.

In describing the mental health gap in SA, Burns ${ }^{[71]}$ correctly points out that psychiatric hospitals remain outdated, in disrepair and unfit for human use. This is true for several institutions in the province, specifically for Elizabeth Donkin Hospital, where several reports recently have indicated inhumane facilities. ${ }^{[72,73]}$

Twenty years after SA's first democratic election, some progress towards achieving the above should be evident. However, very little has changed in the provision of psychiatric services throughout the province. However, the challenge that the Department of Health now faces is surmountable with careful planning and equitable distribution of limited resources. The Eastern Cape stands at the forefront in providing undergraduate medical training with a focus on community care, and this should be the starting point for developing a strong and formidable work force to improve mental health service provision. A retention plan of this work force should enable the creation and development of a mental health service within the primary healthcare system. This must be supported by budgetary allocations for the implementation of such a transformative system.

One lesson from the past should, therefore, be equitable distribution of resources for the provision of care for all that inhabit this province, as is enshrined in SA's constitution. The greatest lesson for psychiatry in general is well summarised in the following extract from Prof. 


\section{Deshoris}

C W Allwood's address to the APA in May 1997: 'We do not wish to be patronised. We do look for collegial acceptance by the international community: a willingness to walk with us in whatever will be to our mutual benefit, as equals trying to find solutions to the world's needs. In this we believe that our experiences have given us something to offer. ${ }^{\text {?[66] }}$

Acknowledgements. This paper was sponsored by an academic fellowship grant from the Discovery Foundation. We would like to thank Associate Prof. TF Jones of the History Department, California State University, San Bernadino, for her comments on mental health practices in apartheid SA.

\section{References}

1. Mostert N. Frontiers: The Epic of South Africas Creation and the Tragedy of the Xhosa People. New York Alfred A Knopf, 1992

2. South African History Online. Cape Province. http://www.sahistory.org.za/places/cape-province (accessed March 2010)

3. Luscombe S. Territory of British Kaffraria. www.britishempire.co.uk, 2010. http://www.britishempire co.uk/maproom/britishkaffraria.htm (accessed March 2010).

4. Bruss GG. An assessment of Sir Benjamin D’Urban's frontier policy 1834-1836. Thesis submitted in partial fulfillment of BA (Hons) degree. Durban, South Africa: University of Natal, 1977.

5. Theal GM. South Africa (The Cape Colony, OFS, SA Republic and All Other Territories South of the Zambesi). London: T Fisher Unwin Ltd, 1894:152.

6. South African Government. Determination of the Amapondo Asenyandeni and Amapondo Aseqauken Paramountecies. http://www.cogta.gov.za/index.php/resources/documents/reports_1/paramountecies reports_1/241-determination-on-amapondo-1/File (accessed March 2010).

7. Mnaba VM. The role of the church towards the Pondo Revolt in South Africa from 1960-1963. Thesi submitted in fulfillment of Master of Theology degree. Pretoria: University of South Africa, 2006.

8. Liebenberg E. Providing a tolerably correct map of South Africa: The cartography of Henry Hall Presentation at the International Symposium on Old Worlds-New Worlds: The history of colonia cartography 1750-1950. Utrecht, The Netherlands: Utrecht University, 21-23 August 2006.

9. Henderson GC. Sir George Grey, Pioneer of Empire in Southern Lands. New York: JM Dent, 1907:132.

10. Henderson GC. Sir George Grey, Pioneer of Empire in Southern Lands. New York: JM Dent, 1907:136.

11. Peires JB. The late great plot: The official delusion concerning the Xhosa cattle killing 1856-1857. Hist Afr 1985;12:235-279. [http://dx.doi.org/10.2307/3171723]

12. Peires JB. The central beliefs of the Xhosa cattle killing. J Afr Hist 1987;28(1):43-63. [http://dx.doi. org/10.1017/S0021853700029418

13. Ure GB. Mental health care in South Africa 1904-2004: Legislation influencing ethical patient care. research report submitted to the Faculty of Health Sciences, University of the Witwatersrand, in partia fulfillment of the MSc Med degree (Bioethics and Law). Johannesburg: University of the Witwatersrand, April 2009. www.wiredspace.wits.ac.za (accessed May 2010)

14. Report of the Provincial Medical Advisor of the Cape of Good Hope, South Africa. BMJ 1912;2(2702):996997. [http://dx.doi.org/10.1136/bmj.2.2702.996]

15. Hofmeyer GS. Grey Hospital King Williams Town: Its formative years. S Afr Med J 1988;70(10):615-617.

16. Burton DW. Valedictory address at Annual General Meeting of the Border Branch. S Afr Med 1956:30(11):278-279.

17. Hospital Reports for 1892 (Cape Colony Blue Book). S Afr Med J 1893;2(November):141-143.

18. Benson RP. Organised medicine in the Eastern Cape. S Afr Med J 1981;60(14):631-638.

19. Theal GM. History of South Africa from 1873-1884: Twelve Eventful Years. Vol. 1. London: George Allen and Unwin Ltd, 1919:155.

20. Report of the asylums and hospitals of the Cape Colony. South African Medical Record 1910;8(19):246247.

21. Patterson RI. Medical missions in the Transkei. S Afr Med J 1943;17(9):154-156

22. Minde M. History of mental health services in South Africa, Part III: The Cape Province. S Afr Med 1974;48(53):2230-2234.

23. Greenlees TD. Hospital and dispensary management. The Grahamstown Asylum, Cape of Good Hope BMJ 1904;1(2251):470-471.

24. Du Plessis R. The influence of moral therapy on the landscape design of lunatic asylums built in the nineteenth century. De Arte 2012;86:19-38.

25. Swartz S. Colonialism and the production of psychiatric knowledge in the Cape, 1891-1920. Thesis presented for the Doctor of Philosophy degree, in the Department of Psychology. Cape Town, South Africa: University of Cape Town, 1996.

26. Greenlees TD. Statistics of Insanity in the Grahamstown Asylum. Cape Town: Townshend, Taylor and Snashall, 1905.

27. Terreblanche M. Readmission and the social construction of mental disturbances. DLitt et Phil dissertation. Pretoria: University of South Africa, 1999

28. Jones TF. Psychiatry, Mental Institutions and the Mad in Apartheid South Africa. London: Routledge, 2012

29. Eastern Cape Department of Health. Provincial Hospitals. http://.www.ecdoh.gov.za/edh (accessed March 2010).
30. Parle J Witchcraft or madness? The Amandiki of Zululand, 1894-1941. J South Afr Stud 2003:29(1):105132. [http://dx.doi.org/10.1080/0305707032000060502]

31. Parle J. The fools on the hill: The Natal Government Asylum and the institutionalisation of insanity in colonial Natal. http://scnc.ukzn.ac.za/doc/Health/Mental/Parle-J_Fools_on_theHill_Lunacy_in_ Colonial_Natal.pdf (accessed October 2010).

32. Parle J. The mad in their midst: Accommodating insanity in Natal, 1868-1920. http://scnc.ukzn.ac.za/ doc/Health/Mental/Parle-J_Mad_in_their_midst_insanity_Natal_Government_Asylum.pdf (accessed October 2010).

33. Swartz S. Colonial Lunatic Asylum Archives: Challenges to Historiography. Cape Town: Kronos, 2008 http://www.scielo.org .za/scielp.php?pid=S0259-01902008000100013\&script=sci_arttext (accessed October 2010).

34. Minde M. History on mental health services in South Africa, Part VII: Services since Union. S Afr Med I 1975;49(9):405-409.

35. Maho J. Select Chronology of South African Legislation: A Reference Guide. Sweden; Department of Oriental and African Languages, Göteborgs University, updated 2002. http://goto.glocalnet.net/jfmaho/ rsalaws.pdf (accessed February 2010).

36. Kaffir Pass Act No. 23, 1857. http://www.nelsonmandela.org/omalley/index.php/site/q/03lv01538/04lv/ 05lv01673.htm (accessed February 2010).

37. Bantu authorities and tribal administration. htpp://www.historicalpapers.wits.ac.za/inventories/ inv_pdfo/AD1715/AD1715-1-2-5-0001-jpeg.pdf (accessed February 2010).

38. Glücksmann R. Apartheid legislation in South Africa. http://ra.smixx.de/Apartheid_Legislation_in South_Africa_2010-2.pdf (accessed June 2010).

39. Marks A. Issues in the political economy of health in Southern Africa. J South Afr Stud 1987;13(2):177=186. [http:///dx.doi.org/10.1080/03057078708708140]

40. Mbeki G. The Transkei Tragedy (A Study in the Bantu Authorities Act). www.disa.ukzn.ac.za/index. php?option=com.displayde\&record 10=LiSep56.1729.45XX.000.021 (accessed June 2010).

41. Hammond-Tooke D. Chieftainship in Transkeian political development. J Mod Afr Studies 1964;2(4):513-529. [http://dx.doi.org/10.1017/S0022278X00004614]

42. Tonkin AH. A state medical service for natives. S Afr Med J 1941;15(15):283.

43. KwaZulu-Natal Department of Health. http://www.kznhealth.gov.za/umzimkhuluhospital.htm (accessed May 2010).

44. Daynes G. Initiation of primary psychiatric care in the Transkei. S Afr Med J 1984;65(22):964-965.

45. Msengi PN, Daynes G. Community response to mental illness in the Transkei. S Afr Med J 1981;59(1):47-49.

46. World Health Organization. Apartheid and Health. Geneva: World Health Organization Press, 1983.

47. Wu M. Between universalism and racism: Tensions in theories of treatment in South African psychiatry. Brown Journal of History 2009:95-113.

48. Dunston JT. Mental hygiene. South African Medical Record 1915;13:299-304.

49. Greenlees TD. The ethics of insanity: An address before the Norwood Division of the British Medical Association. BMJ 1910;2(2588):301-303. [http://dx.doi.org/10.1136/bmi.2.2588.301]

50. Greenlees TD. The etiology, symptoms and treatment of idiocy and imbecility. South African Medical Record 1907;5(2):17-21.

51. Jones TF. Monopoly on madness? Private long-term black institutions in South Africa between 1963 and 1989. Presentation to North Eastern Workshop on Southern Africa 2003. www.solitarytrees.net/pubs/ mithmithtm (accessed September 2012).

52. Zwarenstein MF, Price MR. The 1983 distribution of hospital and hospital beds in RSA, by area, race ownership and type. S Afr Med J 1990;77:448-452.

53. Nel EC. Racial segregation in East London, 1636-1948. South African Geographical Journa 1991;73(2):60-68. [http://dx.doi.org/10.1080/03736245.1991.9713550]

54. Phillips M. The origin of the Public Health Act of 1919. S Afr Med J 1990;77:531-532.

55. Swanepoel M. Human rights that influence the mentally ill patient in South African medical law: A discussion of sections 9;27;30 and 31 of the Constitution. PER/PELJ 2011(14)7: 1-20.

56. Domisse J. Health and health care in post-apartheid South Africa: A future vision. J Natl Med Assoc (988,80(3):325-333.

57. Emsley R. Focus on psychiatry in South Africa. Br J Psychiatry 2001;178:382-386. [http://dx.doi org/10.1192/bjp.178.4.382

58. Sashidharan SP. Mental health and apartheid - a case to answer? Psychiatr Bull 1980,4(11):171-172 [http://dx.doi.org/10.1192/pb.4.11.171]

59. Sashidharan SP. The College and South Africa. Psychiatr Bull 1982;6(5):89-90. [http://dx.doi org/10.1192/pb.6.5.89-a]

60. Sashidharan SP. The College and South Africa. Psychiatr Bull 1983;7(11):208-209. [http://dx.doi org/10.1192/pb.7.11.208-a]

61. Sashidharan SP. South African psychiatry. Psychiatr Bull 1985;9(10):202. [http://dx.doi.org/10.1192 pb.9.10.202]

62. Anderson J, Ben-Arie D, Berg A, et al. Letter to the Editor. Psychiatr Bull 1982;6(2):178-179.

63. Hemphill RE. The College and politics in South Africa. Psychiatr Bull 1982;(6):44. [http://dx.doi. org/10.1192/pb.6.3.44-a]

64. Burke A. Mental health care during apartheid in South Africa: An illustration of how science can be abused. http://www.inter-disciplinary.net/ati/els/els1/burke\%20pap.pdf (accessed October 2010).

65. Levine S. Letter to the Editor. Psychiatr Bull 1982;6:45-46. [http://dx.doi.org/10.1192/pb.6.3.45]

66. Allwood CW. Psychiatry in South Africa: Yesterday, today and tomorrow. S Afr Med J 1997;87(12):1728-1732

67. Health Systems Trust. Health Care in the Eastern Cape. Implications for Planning 1996. Pretoria: Health Systems Trust and the Department of Health, October 1996.

68. Eastern Cape Department of Health. Annual Report 2006/7. www.ecdoh.gov.za (accessed June 2009).

69. KwaZulu-Natal Department of Health. Provincial hospitals. http://www.kznhealth.gov.za/hospitals.htm (accessed May 2010)

70. Freeman M. Mental Health Care Act of 2002. Historical development and current concerns. Presentation at the South African Society of Psychiatrists Conference, 2010.

71. Burns JK. The mental health gap in South Africa: A human rights issue. Equal Rights Rev 2011;6:99-113

72. Kimberley M, Sifile L. Health boss calls for morgue probe. Sowetan, 19 August 2011

73. Gilham S. PE’s Elizabeth Donkin: A hospital of horrors. Weekend Post, 19 April 2012 